\title{
Comparative study of heparin-binding proteins profile of Murrah buffalo (Bubalus bubalis) semen
}

\author{
S. S. Ramteke ${ }^{1}$, A. M. Shende ${ }^{2}$, J. S. Rajoriya ${ }^{1}$, N. C. Barik ${ }^{1}$, Megha Pande ${ }^{3}$, S. K. Bhure ${ }^{2}$, G. K. Das ${ }^{1}$, \\ S. K. Ghosh ${ }^{1}$ and J. K. Prasad ${ }^{1}$
}

1. Germ Plasm Centre, Division of Animal Reproduction, Indian Veterinary Research Institute, Izatnagar, Bareilly, Uttar Pradesh, India; 2. Protein Research Laboratory, Animal Biochemistry Division, Indian Veterinary Research Institute, Izatnagar, Bareilly, Uttar Pradesh, India; 3. Animal Physiology Lab, Central Institute for Research on Cattle, Meerut Cantt, Uttar Pradesh, India.

Corresponding author: S. S. Ramteke, e-mail: drsnehalramteke@rediffmail.com, AMS: asashishivri216@gmail.com, JSR: jituivri@gmail.com, NCB: iamdrncbarik@gmail.com, MP: megha985@gmail.com, SKB: sdbhure@rediffmail.com, GKD: gkdasivri@gmail.com, SKG: subrata_kghosh@yahoo.co.in, JKP: jkprasad2001@yahoo.co.in

Received: 12-06-2014, Revised: 31-07-2014, Accepted: 06-08-2014, Published online: 20-09-2014

doi: 10.14202/vetworld.2014.707-711. How to cite this article: Ramteke SS, Shende AM, Rajoriya JS, Barik NC, Pande M, Bhure SK, Das GK, Ghosh SK, Prasad JK (2014) Comparative study of heparin-binding proteins profile of Murrah buffalo (Bubalus bubalis) semen, Veterinary World 7(9): 707-711.

\begin{abstract}
Aim: The experiment was conducted to study the total seminal plasma protein (TSPP) and heparin-binding proteins (HBPs) in relation to initial semen quality of buffalo bull.

Materials and Methods: Semen from two Murrah buffalo bulls (bull no. 605 and 790) with mass motility of $\geq 3+$ were used for the study and categorized into three groups (Group I- Mass motility 3+, Group II- Mass motility 4+ and Group III- Mass motility 5+). Seminal plasma from semen was separated by centrifugation. HBPs was isolated and purified from heparin-agarose affinity column by modified elution buffer. TSPP and isolated HBPs concentration was estimated by Lowry's method. The purified HBPs were resolved on Sodium dodecyl sulfate polyacrylamide gel electrophoresis to check the protein profile of two bulls.

Results: The mean values of TSPP concentrations in bull no. 605 and 790 in Group I, II and III were 30.64 \pm 0.12 , $31.66 \pm 0.09,32.53 \pm 0.19$ and $28.51 \pm 0.09,29.49 \pm 0.15,30.45 \pm 0.17 \mathrm{mg} / \mathrm{mL}$, respectively. The mean values of HBPs concentrations in bull no. 605 and 790 in Group I, II and III were 3.11 $\pm 0.07,3.32 \pm 0.06,3.46 \pm 0.08$ and 2.51 \pm 0.08 , $2.91 \pm 0.05,3.10 \pm 0.03 \mathrm{mg} / \mathrm{mL}$, respectively. Both the values of TSPP and HBPs were significantly higher $(\mathrm{p}<0.01)$ in bull no. 605 when compared to 790 in all the three groups. $31 \mathrm{kDa}$ HBP was more intensely present in bull no. 605, thus may indicate its superiority over bull no. 790 in relation to fertility potential.

Conclusion: TSPP and HBPs shows variation in concentration with respect to initial semen quality. Furthermore, presence of fertility related $31 \mathrm{kDa}$ HBPs in one of the bull may be an indication of high fertility of a bull. In future, in-vivo and in-vitro correlative study on larger basis is needed for the establishment of fertility-related HBPs in semen which might establish criteria for selection of buffalo bull with high fertility potential.
\end{abstract}

Keywords: buffalo bull, heparin-binding proteins, semen, seminal plasma.

\section{I ntroduction}

Traditional semen quality tests in routine use to evaluate semen quality provide limited information about the potential fertility of bulls and do not provide high correlation or even consistent results of bull fertility. An alternate approach to testing semen quality with more accuracy is the protein fertility marker. A correlation between seminal plasma proteins and fertility of the male have been reported in some of the domestic animals such as cow bull [1], stallion and boar [2], goat [3], and ram [4]. Specific seminal plasma proteins have been identified as potential markers of human male fertility/infertility [5].

Bovine seminal plasma (BPS) contains factors that may have either beneficial and/or detrimental effect to sperm function. Some of these factors are

Copyright: The authors. This article is an open access article licensed under the terms of the Creative Commons Attributin License (http:// creative commons.org/licenses/by/2.0) which permits unrestricted use, distribution and reproduction in any medium, provided the work is properly cited. contributed by accessory sex glands. These are proteinous/non proteinous, but the nature and characteristics of most of these factors are not well-understood [6]. Over the past few decades, special attention has been paid to proteins present in seminal plasma and to their potential roles in sperm maturation events [7].

BPS constitutes of a number of proteins referred as heparin-binding proteins (HBPs) responsible for heparin binding ability of the spermatozoa [8]. These peptides are testosterone dependent and produced by seminal vesicles, prostate and Cowper's glands, binds to sperm during ejaculation as sperm traverse the male reproductive tract [9]. Seminal plasma from a number of mammalian species contains HBPs, which mediate sperm capacitation [10], were associated with fertility due to their modulatory role during the acrosomal reaction [11]. Presence of HBPs in sperm membranes was indicative of the fertility potential of bulls [12]. HBPs modulate capacitation and zona binding ability of buffalo cauda epididymal spermatozoa [13]. 
The total seminal plasma protein (TSPP) concentration in buffalo bulls was ranged from 28 to $36 \mathrm{mg} / \mathrm{mL}[14,15]$ and concentration of buffalo HBPs reported in the range from 1.47 to $2.61 \mathrm{mg} / \mathrm{mL}$ [15-17]. Eight major buffalo HBPs were reported in the molecular weight range of 13-71 $\mathrm{kDa}$ [13]. Until date, the study on buffalo HBPs in terms of their concentration and numbers in relation with initial semen quality is meager.

In the present study, TSPP and HBPs were studied among the ejaculate of a bull and ejaculate between the bulls with the different mass motility. The present study may be helpful in buffalo bull HBPs proteomic research, and characterization - identification of fertility related protein in future.

\section{Materials and Methods}

\section{Climate and experimental animals}

Bareilly is located at $28^{\circ} 10^{\prime}$ North latitude and $78^{\circ} 23^{\prime}$ East latitude at an altitude of $172 \mathrm{~m}$ above the mean sea level, known to have moderate climate. Summer temperature goes up to $40^{\circ} \mathrm{C}$ while winter's goes down up to $8^{\circ} \mathrm{C}$. The rainy season is from June to September with moderate humidity. Two healthy adult Murrah buffalo bulls maintained at Germ-Plasm Center of Animal Reproduction Division, IVRI, Izatnagar, Bareilly, UP, India were utilized for the study.

\section{Chemicals}

All chemicals were reagent grade and purchased from Sigma-Aldrich (St. Louis, MO, USA) and Merck, India.

\section{Experimental animals and semen collection}

Two healthy adult (4-6 years) Murrah buffalo bulls maintained under standard management conditions were used for semen collection for the entire period of study. Semen was collected during morning hours following standard procedure using an artificial vagina.

\section{Semen evaluation}

Semen samples were evaluated for mass motility immediately after collection. Ejaculates having mass motility $3+(0-5$ point scale) and above were selected for study and grouped in three groups (Group I- mass motility 3+, Group II -mass motility $4+$ and Group III- mass motility 5+). Semen samples were aliquoted in $2 \mathrm{~mL}$ microcentrifuge tubes supplemented with protease inhibitor cocktail (P2714, Sigma Aldrich, USA).

\section{Seminal plasma separation}

Each ejaculate was centrifuged initially at $4000 \mathrm{~g}$ for $20 \mathrm{~min}$ at $25^{\circ} \mathrm{C}$ and supernatant was collected. Supernatant was again centrifuged at $10000 \mathrm{~g}$ for $60 \mathrm{~min}$ at $4^{\circ} \mathrm{C}$ to remove suspended spermatozoa and debris, if any. Clear seminal plasma (supernatant) was then stored at $-20^{\circ} \mathrm{C}$ until further processing.

\section{Purification of buffalo HBPs}

Heparin-agarose (HA) matrix (H6508, Sigma Aldrich, USA) was packed in a clean pre-washed plastic column (Bio-Rad, USA) up to $10 \mathrm{~mL}$ level mark. HA column regeneration was done alternately passing $50 \mathrm{~mL}$ each of citrate buffer $(0.1 \mathrm{M}$ citrate buffer, $1.5 \mathrm{M} \mathrm{NaCl}, 0.025 \%$ sodium azide $\left(\mathrm{NaN}_{3}\right)$, $\mathrm{pH}-5.5)$ and Tris-HCl buffer (0.1 M Tris-HCl, $1.5 \mathrm{M}$ $\mathrm{NaCl}, 0.025 \% \mathrm{NaN}_{3}, \mathrm{pH}-8.8$ ). Thereafter, HA column was equilibrated with $50 \mathrm{~mL}$ of Tris-HCl buffer (equilibration buffer; $50 \mathrm{mM}$ Tris-HCl, $150 \mathrm{mM}$ $\left.\mathrm{NaCl}, 0.025 \% \mathrm{NaN}_{3}, \mathrm{pH}-7.4\right)$. One $\mathrm{mL}$ of clear seminal plasma was loaded on to the pre-equilibrated HA column. Once the sample entered HA media, flow was stopped for 10 min to allow binding of HBPs. Column washing was done 5-10 times of bed volume with equilibration buffer to remove unabsorbed proteins, followed by elution of adsorbed HBPs in $2 \mathrm{~mL}$ fractions with modified elution buffer, (50 mM Tris- $\mathrm{HCl}$, $800 \mathrm{mM} \mathrm{NaCl}, 0.025 \% \mathrm{NaN}_{3}, \mathrm{pH}$ 7.4). The absorbance of eluted proteins was taken at $280 \mathrm{~nm}$ on spectrophotometer (Spectramax M5, Molecular Devices, USA). The fractions containing proteins were pooled and concentrated by protein concentrator tube (Amicon, Ultra 15, 10K, Merck-Millipore, India). The concentrated proteins was then dialyzed against Tris buffer (20 mM Tris, $20 \mathrm{mM} \mathrm{NaCl}, \mathrm{pH}$ 7.4) and stored at $-20^{\circ} \mathrm{C}$ until further use.

\section{Estimation of protein concentration}

TSPP and purified HBPs concentration were estimated as per the method given by Lowry [18].

\section{Sodium dodecyl sulfate polyacrylamide gel electro- phoresis (SDS-PAGE)}

The isolated and purified HBPs were analyzed by 18\% SDS-PAGE as described [19] using Coomassie Brilliant Blue G-50 stain. The apparent molecular mass was determined by using molecular weight marker (PG-PMT2922, Genetix Biotech Asia Ltd., India) Gel documentation and analysis system (Gel-Doc ${ }^{\mathrm{XR}}$, Bio-Rad, USA).

\section{Statistical analysis}

To minimize the variation in the subjective evaluation of the present study, each sample was evaluated in duplicate and average was analyzed using SPSS version 18.0, (IBM Software Company, USA). Analysis of variance (ANOVA) was performed for statistical analysis of data, using PROC GLM of SAS 9.3 software (SAS Institute Inc., USA) for estimation of mean and standard error of variables under investigation. ANOVA and t-test were used for the comparison between the bulls for the variables viz., TSPP and respective HBPs.

\section{Results and Discussion}

TSPP

The mean value of TSPP concentrations in bull no. 605 and 790 in Group I, II and III were $30.64 \pm 0.12, \quad 31.66 \pm 0.09, \quad 32.53 \pm 0.19$ and $28.51 \pm 0.09, \quad 29.49 \pm 0.15, \quad 30.45 \pm 0.17 \mathrm{mg} / \mathrm{mL}$, respectively (Table-1). The TSPP concentration was 
significantly $(p<0.01)$ higher in Group III when compared to Group I and II in both the bulls. TSPP levels of all the groups in bull No. 790 were significantly $(\mathrm{p}<0.01)$ lower than bull no. 605, which might be due to lower level of plasma testosterone [20] and health status of accessory sex glands [21]. The TSPP values in present study ranged from 28.51 to 32.53 , which were in agreement $(28-33 \mathrm{mg} / \mathrm{mL})$ with previous researcher [14-16]. Variation in the concentration of TSPP in split ejaculates from the same Holstein bull and within the bull was also observed [22]. The variation in the buffalo TSPP concentration might be due to individual bull variation, age, inherent character, size, season and health status of seminal vesicle [21] and other factors.

\section{HBPs concentration and electrophoretic profile}

Overall mean value of HBPs concentrations in bull no. 605 and 790 in Group I, II and III was $3.11 \pm 0.07, \quad 3.32 \pm 0.06, \quad 3.46 \pm 0.08$ and $2.51 \pm 0.08$, $2.91 \pm 0.05,3.10 \pm 0.03 \mathrm{mg} / \mathrm{mL}$, respectively (Table- 1 ). The bull no. 605 showed significantly $(\mathrm{p}<0.01)$ higher HBPs concentration when compared to bull no. 790 in all the three groups. HBPs level was significantly $(p<0.01)$ higher in Group III for bull no. 605 and also significantly $(\mathrm{p}<0.01)$ higher in both Group II and III than Group I for bull no. 790.

In the present study, the overall mean values of HBP ranged from 2.84 to $3.30 \mathrm{mg} / \mathrm{mL}$ and found greater than the previously reported concentrations $2.61 \mathrm{mg} / \mathrm{mL}$ [13], $2.01 \mathrm{mg} / \mathrm{mL}$ [17] and 1.15-2.18 mg/mL [23,24]. Variation in the concentration of BPS in split ejaculates from the same Holstein bull and within the bull was also observed [22]. HBP in seminal plasma may positively influence fertility [1].

SDS-PAGE analysis of isolated HBPs was done to assess the number of purified HBPs (Figure-1) in individual bull. In the present study HBPs showed 11-14 protein bands on SDS-PAGE in the molecular weight range of 11-129 $\mathrm{kDa}(11,14,15,16,20$, 28, 29, 31, 43, 48, 53, 71, 92 and 129) and of varying intensity in the Coomassie stained gel. Previous reports indicated 6 to 9 buffalo HBP bands $[13,17,24]$. In bull no. 605 there was the absence of three HBP bands at 20, 92 and $129 \mathrm{kDa}$ positions, however, in bull no. 790 only one HBP band was absent at $29 \mathrm{kDa}$ positions. Variation in the intensity at 14, 15, 16, 31 and $71 \mathrm{kDa}$ HBP was also observed in bull no. 605 and 790 (Figure-1), which shows the variation in their respective concentration in the seminal plasma. Absence or presence of a particular HBP in the seminal plasma may be associated with fertility potential of a bull. Presence of $31 \mathrm{kDa}$ HBP (fertility associated antigen) showed better conception in cattle bull has been reported [25]. In the present study also, a $31 \mathrm{kDa}$ HBP was more intensely present in bull no. 605, thus might indicate its superiority over bull no. 790 in relation to fertility potential.

The variation in concentration and number of HBPs within and between the bulls might be due to testosterone dependent secretary activity of accessory sex glands [9], health status of accessory sex glands [26] and inherent character of an individual bull. Furthermore, aggregation product of low molecular weight proteins or degradation product of high molecular weight proteins [13] may alter the HBPs profile of a bull.

Variation in TSPP and HBPs concentration and number of HBPs between the bulls may be an indicative of low or high fertility potential of a bull. To the author's best knowledge, no literature is available in this regard. To establish any such correlation would require screening of a large number of ejaculates from number of bulls. Thus, further study is needed on a

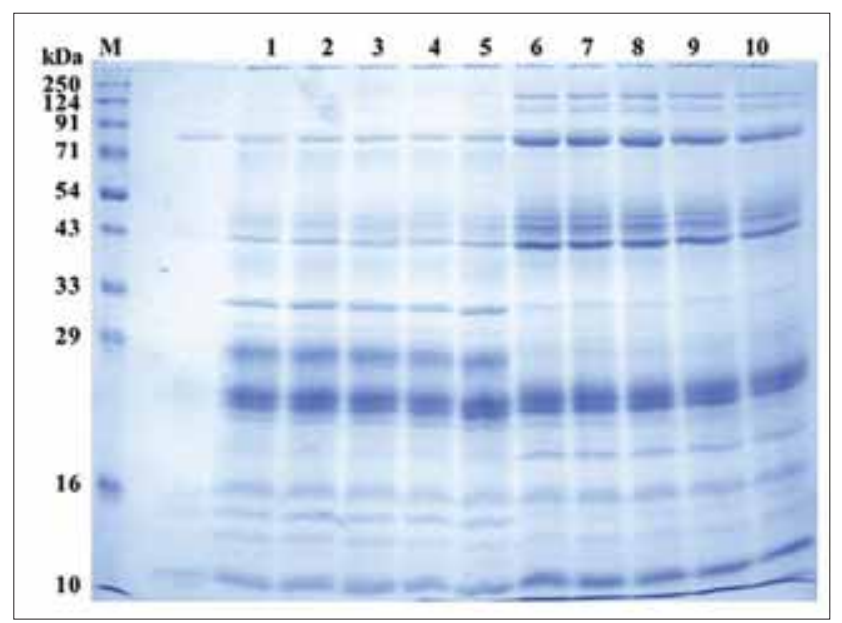

Figure-1: Sodium dodecyl sulfate polyacrylamide gel electrophoresis (SD-PAGE) of heparin binding proteins (HBPs) of buffalo bull 605 and 790. Lane M: Marker; Lane 1,2,3,4 and 5: HBPs of bull number 605; Lane 6,7,8,9 and 10: HBPs of bull number 790 .

Table-1: Concentration of TSPP and HBPs from semen of buffaloes (mean \pm SE).

\begin{tabular}{|c|c|c|c|c|}
\hline \multirow[t]{2}{*}{ Groups } & \multicolumn{2}{|c|}{ TSPP ( $\mathrm{mg} / \mathrm{mL}$ ) } & \multicolumn{2}{|c|}{ HBPs (mg/ mL) } \\
\hline & $\begin{array}{c}\text { Bull number } \\
605(n=4)\end{array}$ & $\begin{array}{c}\text { Bull number } \\
790(n=4)\end{array}$ & $\begin{array}{c}\text { Bull number } \\
605(n=4)\end{array}$ & $\begin{array}{c}\text { Bull number } \\
790(n=4)\end{array}$ \\
\hline Group I (MM- 3+) & $30.64 \pm 0.12^{\mathrm{Ca}}$ & $28.51 \pm 0.09 \mathrm{cb}$ & $3.11 \pm 0.07^{\mathrm{Bx}}$ & $2.51 \pm 0.08^{\text {By }}$ \\
\hline Group II (MM- 4+) & $31.66 \pm 0.09 \mathrm{Ba}$ & $29.49 \pm 0.15^{\mathrm{Bb}}$ & $3.32 \pm 0.06^{\mathrm{ABx}}$ & $2.91 \pm 0.05^{\mathrm{Ay}}$ \\
\hline Group III (MM- 5+) & $32.53 \pm 0.19^{\mathrm{Aa}}$ & $30.45 \pm 0.17^{\mathrm{Ab}}$ & $3.46 \pm 0.08^{\mathrm{Ax}}$ & $3.10 \pm 0.03^{\mathrm{Ay}}$ \\
\hline Overall mean & $31.61 \pm 0.24^{a}$ & $29.48 \pm 0.25^{b}$ & $3.30 \pm 0.06^{x}$ & $2.84 \pm 0.08^{y}$ \\
\hline
\end{tabular}

Means bearing different superscripts $(a, b$ and $x, y)$ in a row differ significantly $(p<0.01)$, Means bearing different superscripts $(A, B$ and $C)$ in a column differ significantly $(p<0.01)$. $n=$ number of ejaculates, MM=Mass motility, $\mathrm{TSPP}=$ Total seminal plasma protein, $\mathrm{HBPs}=$ Heparin binding proteins, $\mathrm{SE}=$ Standard error 
larger basis, which might be helpful in the selection of buffalo bull with high fertility.

\section{Conclusion}

In the present study, one of a bull (No. 605) showed significantly $(\mathrm{p}<0.01)$ higher concentration of TSPP and HBPs in relation to initial semen quality. Furthermore, more intensity of $31 \mathrm{kDa}$ HBP in the same bull might reflect its better fertility potential. In the future, in-vivo and in-vitro correlative study on a larger basis is needed for the establishment of fertility related HBPs in semen that might establish the criteria for selection of buffalo bull with high fertility potential.

\section{Authors' Contributions}

The present study is a part of the Ph.D. thesis program of SSR under approved Institutional research project "isolation and characterization of HBP with special reference to PDC-109 as a fertility marker of buffalo bull” sponsored by Indian Veterinary Research Institute, Izatnagar. JKP is the principal investigator of the project and supervisor of Student Advisory Committee, JKP, SKG, SKB, GKD and SSR planned and designed the research work. Experimental semen collection, grading of semen, seminal plasma separation was done by JSR, MP and NCB. Isolation of HBPs, estimation of TSPP, HBPs and SDS-PAGE analysis was done by SSR and AMS. The manuscript was prepared by SSR and was supervised, reviewed and edited by JKP, SKG, SKB and GKD. All authors have read and approved the final manuscript.

\section{Acknowledgments}

The authors are thankful to Director, Indian Veterinary Research institute, for providing facilities and fund during thesis research work of the first author. Also, we thankfully acknowledge, Dr. Yogesh Bangar for his help during statistical analysis.

\section{Competing I nterests} interests.

The authors declare that they have no competing

\section{References}

1. Killian, G.J., Chapman, D.A. and Rogowski, L.A. (1993) Fertility associated proteins in Holstein bull seminal plasma. Biol. Reprod., 49(6): 1202-1207.

2. Calvete, J.J., Raida, M., Gentzel, M., Urbanke, C., Sanz, L. and Topfer-Petersen, E. (1997) Isolation and characterization of heparin - And phosphorylcholine-binding proteins of boar and stallion seminal plasma: primary structure of porcine pB1. FEBS Lett., 407(2): 201-206.

3. Villemure, M., Lazure, C. and Manjunath, P. (2003) Isolation and characterization of gelatin-binding proteins from goat seminal plasma. Reprod. Biol. Endocrinol., 1: 39.

4. Jobim, M.I.M., Oberst, E.R., Salbego C.G., Wald, V.B., Horn, A.P., and Mattos, R.C. (2005) BSP A1/A2-like proteins in ram seminal plasma. Theriogenology, 63(7): 2053-2062.

5. Martınez-Heredia, J., de Mateo, S., Vidal-Taboada, J.M., Ballesca, J.L. and Oliva, R. (2008) Identification of proteomic differences in asthenozoospermic sperm samples. Hum. Reprod., 23(4): 783-791.
6. Manjunath, P., Bergeron, A., Lefebvre, J., and Ton, J. (2008) Seminal plasma proteins: Function and interaction with protective agents during semen preservation. Biochem. Biophy. Acta., 1784: 891-899.

7. Manjunath, P., Lefebvre, J., Jois P.S., Fan, J. and Wright, M.W. (2009) New nomenclature for mammalian BSP genes. Biol. Reprod., 80(3): 394-397.

8. Miller, D.J., First, N.L. and Ax, R.L. (1987) Isolation and characterization of seminal fluid proteins that bind heparin. Adv. Exp. Med. Biol., 219: 597-601.

9. Nass, S.J., Miller, D.J., Winer, M.A. and Ax, R.L. (1990) Male accessory sex glands produce heparin-binding proteins that bind to cauda epididymal spermatozoa and are testosterone dependent. Mol. Reprod. Dev., 25(3): 237-246.

10. Calvete, J.J., Sanz, L., Reinert, M., Dostalova, Z. and TopferPetersen, E. (1995) Heparin binding proteins on bull, boar, stallion, and human spermatozoa. In: Jamieson, B.G.M., Ausio, J. and Justine J.L. editors. Advances in Spermatozoal Phylogeny and Taxonomy. Vol. 166. Memoires du Museum National D’Histoire Naturelle, Paris. p515-524.

11. Manjunath, P., Chandonnet, E., Leblond, E. and Desnoyers, S.L. (1993) Major proteins of bovine seminal plasma bind to spermatozoa. Biol. Reprod., 49: 27-37.

12. Bellin, M.E., Hawkins, H.E., Oyarzo, J.N., Vanderboom, R.J. and Ax, R.L. (1995) Monoclonal antibody detection of heparin-binding proteins on sperm corresponds to increased fertility of bulls. J. Anim. Sci., 74(1): 173-182.

13. Arangasamy, A., Singh, L.P., Ahmed, N., Ansari, M.R. and Ram, G.C. (2005) Isolation and characterization of heparin and gelatin binding buffalo seminal plasma proteins and their effect on cauda epididymal spermatozoa. Anim. Reprod. Sci., 90(3-4): 243-254.

14. Harshan, H.M. (2007) Modulation of structural and functional properties of buffalo cauda epididymal spermatozoa by sperm binding seminal plasma protein (PDC-109). $\mathrm{Ph}$. D. Thesis Submitted to Deemed University IVRI, Izatnagar, U.P., India.

15. Singh, M. (2012) Isolation and purification of PDC-109 protein from buffalo seminal plasma and its relation with freez ability. M.V.Sc. Thesis Submitted to Deemed University IVRI, Izatnagar, U.P., India.

16. Arangasamy, A. (2003) Isolation of buffalo seminal plasma proteins and their effect on in vitro capacitation, acrosome reaction and fertilizing potential of spermatozoa. Ph. D. Thesis Submitted to Deemed University IVRI, Izatnagar, U.P., India.

17. Kumar, A. (2005) Effect of seminal plasma heparin binding and non-heparin binding proteins on the freezability and in vitro fertility of buffalo cauda spermatozoa. M.V.Sc. Thesis Submitted to Deemed University IVRI, Izatnagar, U.P., India.

18. Lowry, O.H., Rosenberg, N.J. Farr, A.L. and Randall, R.J. (1951) Protein measurement with the folin phenol reagent. J. Biol. Chem., 193(1): 265-275.

19. Laemmli, V.K. (1970) Cleavage of structural proteins during the assembly of the head of bacteriophage T4. Nature., 227(5259): 660-685.

20. Kulkarni, B.A., Rupal, R.K. and Hegde, U.C. (1998) Comparative SDS-polyacrylamide gel electrophoresis of seminal plasma proteins and blood plasma proteins of the Indian buffalo and cattle bulls. Indian. J. Anim. Sci., 68: 66-67.

21. Rahman, M.S., Islam, M.S., Rahman, M.T., Parvez, N.H. and Rhaman, M.M. (2010) Morphometric analysis of vesicular glands of indigenous bull. Int. J. Sustain. Crop. Prod., 5: 11-14.

22. Nauc, V. and Manjunath, P. (2000) Radio immunoassays for bull seminal plasma proteins (BSP-A1/A2, BSP-A3, and BSP-30- kilo Daltons) and their quantification in seminal plasma and sperm. Biol. Reprod., 63(4): 1058-1066.

23. Singh, M., Ghosh, S.K., Prasad, J.K., Kumar A., Tripathi, R.P., 
Bhure, S.K. and Srivastava, N. (2014) Seminal PDC-109 protein vis-à-vis cholesterol content and freezability of buffalo spermatozoa. Anim. Reprod. Sci., 144(1-2): 22-29.

24. Singh, M., Ghosh, S.K., Prasad, J.K., Kumar A., Ramteke, S.S., Srivastava, N. and Rajoriya J.S. (2014) Isolation, characterization and quantitation of heparin binding proteins and PDC-109 protein from buffalo bull semen. Indian. Vet. J., 91(2): 27-29.
25. Bellin, M.E., Oyarzo, J.N., Hawkins, H.E., Zhang, H.M., Smith, R.G., Forest, D.W., Sprott, L.R. and Ax, R.L. (1998) Fertility-associated antigen on bull sperm indicates fertility potential. J. Androl. Sci., 76(8): 2032-2039.

26. Shinde, S., Mahmood, S., Singh, G. and Verma, M.R. (2014) Association between the seminal vesicle weight and certain steroids in buffaloes (Bubalus bubalis). Vet. World., 7(1): 21-25.

$* * * * * * * *$ 